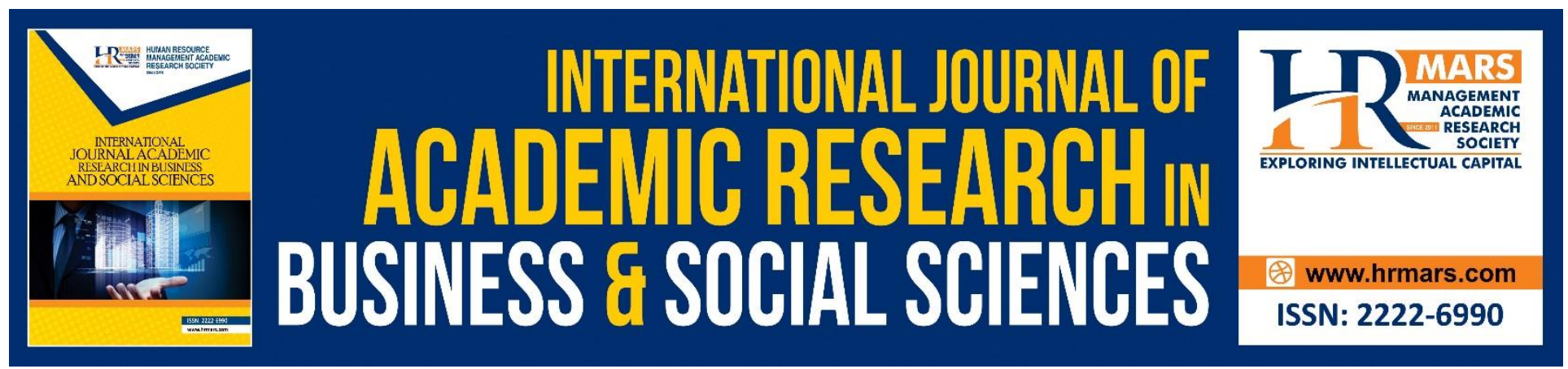

\title{
Factors that Influence the Ethical Behaviours of Takaful Agents
}

Nor Arini Abdullah, Shahir Akram Hassan, Siti Zanariah Yusoff

To Link this Article: http://dx.doi.org/10.6007/IJARBSS/v10-i8/7535

DOI: 10.6007/IJARBSS/v10-i8/7535

Received: 08 May 2020, Revised: 04 June 2020, Accepted: 20 July 2020

Published Online: 16 August 2020

In-text Citation: (Abdullah, Hassan, Yusoff, 2020)

To Cite this Article: Abdullah, N. A., hassan, S. A., Yusoff, S. Z. (2020). Factors that Influence the Ethical behaviours of Takaful Agents. International Journal of Academic Research in Business and Social Sciences. 10(8), 270-282.

\section{Copyright: (C) 2020 The Author(s)}

published by Human Resource Management Academic Research Society (www.hrmars.com) this article is published under the creative commons attribution (cc by 4.0) license. anyone may reproduce, distribute, translate and create derivative works of this article (for both commercial and non-commercial purposes), subject to full attribution to the original publication and authors. the full terms of this license may be seen

at: http://creativecommons.org/licences/by/4.0/legalcode

\section{Vol. 10, No. 8, 2020, Pg. 270 - 282}

Full Terms \& Conditions of access and use can be found at http://hrmars.com/index.php/pages/detail/publication-ethics 


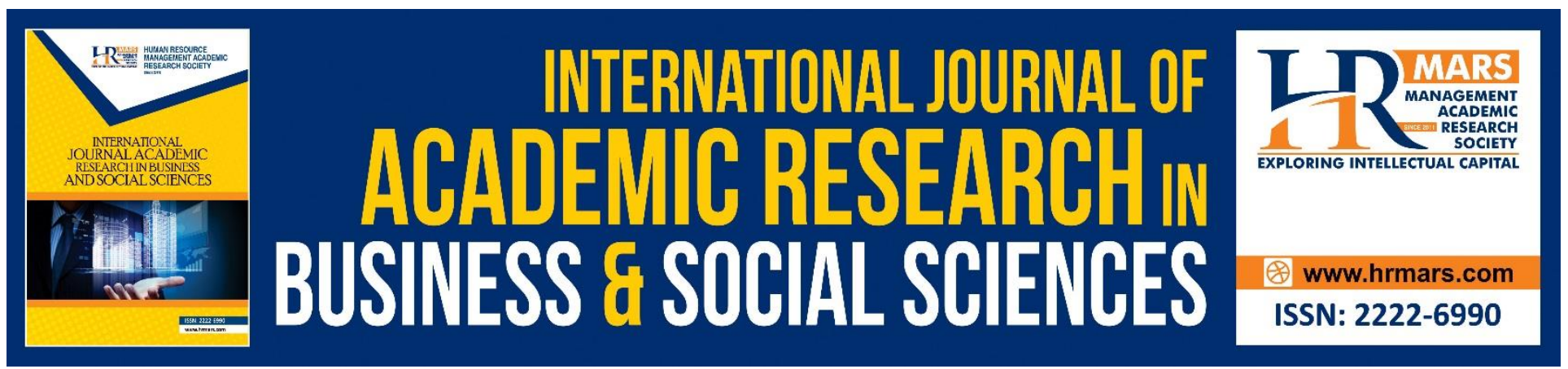

\title{
Factors that Influence the Ethical Behaviours of Takaful Agents
}

\section{${ }^{1}$ Nor Arini Abdullah, 2Shahir Akram Hassan, 3Siti Zanariah Yusoff}

${ }^{1}$ Centre For Islamic Development management Studies, Universiti Sains Malaysia, Pulau Pinang, 11800, Malaysia, ${ }^{2}$ Centre For Islamic Development management Studies, Universiti Sains Malaysia,

Pulau Pinang, 11800, Malaysia, ${ }^{3}$ Centre of Modern Languages and Communication, Faculty of

Languages and Communication, Universiti Sultan Zainal Abidin, 21300 Kuala Nerus, Terengganu

Email: zanariahyusoff@unisza.edu.my

\begin{abstract}
Most takaful companies in Malaysia require an agent as a representative for them to promote products and takaful services to the community. The agent receive rewards in the form of commission depending on his subscription. However, in conducting the job as an agent in promoting takaful products and dealing with customers on behalf of the company, there are a few ethical issues that arise. Some of the issues include being deceitful in explaining a product or takaful service, giving false information, hiding information and delaying settlement claim. Therefore, the matter arises of the factors that influence these agents' behaviours. How does these factors influence the performance of the takaful industry? Does the factors influencing the takaful agents' behaviours lead to an ethical or non-ethical person? To answer these questions, this paper has two objectives. Firstly, this paper is written to identify ethics and factors that influence takaful agents' behaviours. Secondly, the paper is written to analyse these ethics and factors that influence takaful agents' behaviours. The paper applies a qualitative approach by employing document analysis. Next, the data obtained will be analysed using content analysis method. The findings of the study show that target sales are one of the dominant factors that influence behaviour among takaful agents. Hence, based on the findings of this study, this paper offers two main suggestions. Firstly, the management of takaful company needs to create positive working environment among takaful agents. Apart from that, takaful companies must also have a strong level of leadership in terms of character, values and ethical behaviour.
\end{abstract}

Keywords: Ethic, Agent, Factors, Behaviours, Takaful.

\section{Introduction}

Takaful agents are the representatives of takaful companies. Their job scopes include promoting products and services that are offered by the takaful company that they represent (Zulkifli, Abd Rahman, Yassin \& Ramly, 2012). In performing the duties as a representative of a takaful company, an agent must be equipped with in-depth knowledge on the products and services that are offered 
INTERNATIONAL JOURNAL OF ACADEMIC RESEARCH IN BUSINESS AND SOCIAL SCIENCES Vol. 10, No. 8, 2020, E-ISSN: 2222-6990 @ 2020 HRMARS

by the company. Besides, the agent must also understand his customers' needs and make sure that the customers fully comprehend the available plans. Agent must explain the truthful information of the stated products and takaful services accurately. Takaful agents must also be responsible to its principal company in assisting the selection of risks (Segar, 2009). Most importantly, takaful agents must carry out their duties truthfully, sensibly and attentively. When a takaful agent communicates with a takaful participant, he must appear professional as he represents the company he works for. Lastly, the agent must also help participants in the process of being a takaful participant.

However, there are a few ethical issues that arise regarding takaful agents when they carry out their duties. A takaful agent must have integrity and credibility in promoting and explaining a particular product and giving services to a customers. If such qualities are disregarded, issues arise as the agents may become dishonest in explaining a particular product or takaful service, give false information, hide information and delay settlement claims. These negative qualities are wrong as customers rely heavily on takaful agents to help them in subscribing to suitable plans and schemes for them.

If these ethical issues arise and agent does not disclose the actual situation to the company, the company may revoke agency contract, reclaim wages received by the agent and withdraw the right of the agent to perform his duties (Fresh, 2009).

Therefore, the questions arise. What are the factors that influence takaful agents' behaviours? How do these factors affect the performance of the takaful industry? Does the factors lead to ethical behaviours or non-ethical? This paper there hence has two objectives. Firstly, the researchers aim to identify the ethics and factors influencing takaful agents' behaviours. Secondly, the researchers intend to analyse these ethics and factors that influence the takaful agents' behaviours.

\section{Literature Review}

Ethics is a critical issue in every organisations, especially those in relation to financial services (Dunfee \& Gunther, 1999). In an organisation, agents are the most accessible representatives for customers (Crosby, Evans \& Cowles, 1990). According to The Islamic Financial Services (2013), takaful agents are the representatives of takaful companies who seek proposals for takaful certificates, offer or take part in negotiating takaful certificates, handle issuance, renewal and continuation of takaful certificates on behalf of takaful companies. In the takaful industry, these agent will always communicate with customers as they represent the takaful company.

Takaful agents need to have professional ethical code standards when dealing with customers (Zulkifli, Abd Rahman, Yassin \& Ramly, 2012). According to Zulkifli, Abd Rahman, Yassin and Ramly (2012), a takaful agent should understand customers' needs and assist them in selecting takaful products and services that are suitable.

In dealing with customers, takaful agents must adhere to the code of ethic that are set by the company. An agent may lose their customer's confidence in them if they behave unethically. As a result, customers' dissatisfaction with the services provided by the agent will occur. Although takaful companies have established guidelines and codes of ethics that agents must adhere to, there are situations and opportunities that may prompt an agent to act unethically (Lagace, Dahlstrom \& Gassenheimer, 1991).

Work environment is one of the reasons that cause agents to act unethically in a given situation and opportunity (Djafri \& Nordin, 2017). Djafri and Nordin (2017) stated that takaful agents tend to work longer hours with short leaves as companies rely on them to increase profitability and expand takaful 
INTERNATIONAL JOURNAL OF ACADEMIC RESEARCH IN BUSINESS AND SOCIAL SCIENCES Vol. 10, No. 8, 2020, E-ISSN: 2222-6990 @ 2020 HRMARS

markets. As a result, these agents are highly likely to feel pressured at work. Eventually, pressure at workplace will lead to negative impacts such as agents being uninterested to improve their knowledge and skills. Indirectly, they will not be able to convince takaful customers of the takaful policy that they are promoting. In the long run, a reduction in sale will occur and agents will likely leave the takaful company that they work for.

The attitude and ethics of the takaful agent also influence customers' satisfaction and participation in takaful schemes (AINemer, 2015). Bashir (2013) also stated that agents with good service quality will enhance customers' satisfaction in participating in takaful. Yazid et al., (2017) holds the similar view as Bashir (2013). He stated that good takaful agents are able to attract and encourage takaful participants to continue joining in takaful schemes (Yazid et al., 2017). On the contrary, participants may opt out of the existing takaful schemes should agents with unethical behaviours make them feel dissatisfied (Salleh, 2014; Jamil \& Akhter, 2016; Amin \& Hamid, 2014).

Takaful agents are responsible in recruiting takaful participants who wish to join takaful scheme. The agents are also in charge to explain takaful policy. Hence, it is clear that the role of the agents is an important criteria in determining customer's satisfaction to choose a takaful scheme (Shaladdin, Mokhtar, \& Zawawi, 2018). Haslina, Kartini and Norudin (2016) hold the same view as they stated that a takaful agent can provide good satisfaction and treatment to a takaful participant which will increase encouragement of participants to take up takaful scheme with high monthly premium rates. Agents' attitude are important too as they are the ones providing customer service. Their customer service will affect customers' understanding of takaful products. If customers are satisfied with the information and services provided by the agent, he or she will participate willingly (Roushdy \& Ali, 2017; Isaac, 2017).

\section{Sales Target Pressure}

Haron, Ismail and Abdul Razak (2011) have studied the factors that influence unethical behaviour among agents. They found that sales target is one of the dominant factors that affects takaful agents' behaviour. Similarly, Aziz, Ghani \& Shaari, (2016) claimed that sales target is also a major factor in affecting takaful agents' behaviour.

Yi, Dubinky \& Lim (2012) found that sale pressure and competition are the factors that influence agents to behave unethically. Their study shows that the higher the sales that needs to be met, the higher the probability of agents to behave unethically. In addition, competition among agents also indicates for higher unethical behaviour. Yi, Dubinky \& Lim (2012)also explained that agents' perceptions of competition in the financial industry can influence their ethics. Supervisors' influence and role ambiguity have also been described by Haron, Ismail and Razak (2011) as factors affecting takaful agents' behaviour

Unethical behaviours among agents are increasing steadily due to their sales target rate. Aziz, Ghani and Shaari (2016) mentioned that agents consciously or unconsciously act out of their control while performing tasks. The reason being is that they want to reach the sales target set by the company.

\section{Supervisor's Influence}

Talha, Sallehhuddin \& Masoud (2014) and Haron, Ismail \& Razak (2011) stated that supervisors' influence is also one of the causes for agents to behave unethically. Talha, Sallehhuddin and Masoud (2014) have listed several behaviours that agents must adhere to. This includes avoiding giving false 
information, providing fair and equitable services to takaful users, conducting transactions with integrity and trust and not misleading customers about takaful products and services.

Both of these studies suggest two factors that may influence agents to behave unethically. Firstly is the role of important and close people to the agents and second is motivation. The role of important people among agents are those who have direct contact with them, especially in the workplace. This includes employees and colleagues. Motivation on the other hand, depends on the agent's intentions. If the agent himself is willing to behave unethically, the agent will tend to engage in unethical activities.

\section{Competition}

Aziz, Ghani \& Shaari (2016) and Yi, Dubinky \& Lim (2012) have mentioned on competition being a factor influencing agents' behaviours. Their study stated that high competition between agents contributes to unethical behaviour. However, at the same time, competition is emphasised when working in a group as they need to compete to meet the sales target. Yi, Dubinky \& Lim (2012) also explained that agents' perception in the financial industry may affect their ethics. They must compete with their colleagues to reach target sales. Therefore, every agents needs their own creative strategies in promoting ad advertising products to attract customers (Aziz, Ghani \& Shaari, 2016).

\section{Job Satisfaction and Work Commitment}

Job satisfaction and work commitment influence the performance of the takaful industry (Hamid and Rahman, 2011). Their research showed that job satisfaction consisting of role conflict and role ambiguity are the factors that influence the performance of takaful industry. These indirectly affect the behaviour of agents. Agents with positive behaviour will achieve good takaful industry performance while agents with negative behaviours will achieve poor takaful performance. Therefore, if role and ambiguity conflict exist within the agent, the probability of agent being unethical is high.

Role conflict occurs when agents feel incompatible and uncomfortable with the work performed. Role conflict also occurs when the agents' co-workers have high expectations for their work. Role ambiguity, on the other hand, occurs when the agent is unable or unsure of how to perform the task. This occurs due to agents not having enough knowledge and information of the product and the takaful plan.

As a result, job satisfaction of the agent will be negatively impacted. Therefore, it is clear that role conflicts and ambiguities do influence the takaful agent's behaviour to be unethical in carrying out his duties.

Rahman, Akhter \& Khan (2017) stated that job satisfaction has a significant impact on job performance, job growth, development and good relationship with supervisors and colleagues. This shows that if agents feel satisfied or happy when working, the probability of the agent behaving negatively will decrease. On the contrary, if agents feel dissatisfied when working, he will likely be influenced by unethical behaviour.

An increase in job satisfaction leads to a positive work environment (Rahman, Akhter \& Khan, 2017). Therefore, researchers can conclude that job satisfaction is one of the factors that can affect the behaviour of takaful agents. 
INTERNATIONAL JOURNAL OF ACADEMIC RESEARCH IN BUSINESS AND SOCIAL SCIENCES Vol. 10, No. 8, 2020, E-ISSN: 2222-6990 @ 2020 HRMARS

\section{Individual Personality}

Salleh and Kamaruddin (2011) showed that self-confidence and self-monitoring are factors that influence an agent's performance. From their findings, Salleh and Kamaruddin (2011) concluded that low self-esteemed agents may achieve poor performance and therefore can affect takaful agents' behaviours. In addition, low self-monitoring can lead to poor performance among agents. This is because agents who are unable to adapt to different situations may not earn a lot of commissions. Low self-confidence and self-monitoring will make it difficult for agents to reach their sales targets. Consequently, such personalities will influence the agents' behaviour whether it is good or bad.

\section{Takaful agents' leadership}

Hamid, Rahman and Nor (2012) also explained that the performance of the takaful industry depends on takaful agents' leadership behaviours. Their study found that communication skills (persuasiveness), tasks understanding (initiating structure), customers' demand/ needs (consideration) and self-confidence are leadership factors that are impactful to takaful performance. Therefore, researchers have identified that these four factors can also affect takaful agents' behaviours. If the agent does not know how to communicate, do the tasks that need to be done, not confident and does not know customers' needs, the probability of the agent providing vague information while persuading customers to choose unneeded products will increase. As a result, the probability of agents to be unprofessional in their task will increase.

\section{Age}

Cheng, Hsieh \& Yang (2014) have listed five types of unethical behaviour among agents. First is providing inaccurate and false information on products and services. Secondly, failure to recommend products to customers; third, lack of understanding of concepts, knowledge and skills to fulfil their responsibilities as agents; fourth, failure to perform due to commission conflict, and lastly, misconduct that could damage the company's reputation.

They found out that age and work experience are the most dominant factors in influencing agents' behaviour. It was revealed in their studies that respondents over the age of 50 have great influence in behaving unethically while performing duties as agents.

Román \& Munuera (2005) also explained that senior agents have bigger influence. Their behaviours are somewhat more conservative. Age is deemed one of the factors influencing an agent's behaviour because the longer one serves in an industry, the more dilemma and behaviours, ethical or nonethical, that he will be exposed to.

\section{Experience and rewards}

Cheng, Hsieh \& Yang (2014) stated that work experience is also significantly related to unethical behaviours among agents. This is especially true with agents that have more than 10 years of experience. In addition, Román \& Munuera (2005) also found that rewards affect agents' behaviour. This is because rewards provided by companies tend to motivate agents to behave differently when dealing with customers.

Therefore, in order to be rewarded when sales target are reached, agents tend to behave mischievously by hiding certain information for their personal benefits. 
INTERNATIONAL JOURNAL OF ACADEMIC RESEARCH IN BUSINESS AND SOCIAL SCIENCES Vol. 10, No. 8, 2020, E-ISSN: 2222-6990 @ 2020 HRMARS

According to the results gathered, a table is applied to list the factors that influence agents' behaviours found by past researchers. Table 1 below provides a summary of the factors affecting agent behaviour.

Table 1: A summary of factors influencing agents' behaviours

$\begin{array}{cl}\text { No. Title } & \text { Researcher } \quad \begin{array}{l}\text { Results of Study on } \\ \text { Factors Influencing } \\ \text { Behaviours }\end{array}\end{array}$

1 unethical behavior

Factors influencing of Insurance agents
-Supervisor's
Haron, Ismail, \& influence
Abdul Razak
-Role ambiguity
-Sales target pressure

2011

Talha,

Sallehhuddin, \& Masoud

behavior among

insurance agents
3 Issues and problem in
ethical practices
amongst Takaful
agents
Who would engage in
4
unethical behavior?
Should organizations
bear the responsibility?
Determinants
of
5 telemarketer misselling
in life insurance
services
Leadership behavior
6
case study of Takaful
representatives in
Malaysia

Abdul Aziz, Abdul

Ghani \& Shaari

Cheng, Hsieh, C \&

Yang

Taek Yi, Dubinky \&

Un Lim

-Sales target pressure

-Competition

2012

-Role conflict

Abdul Hamid \& Nik -Role ambiguity

Ab Rahman

-Work commitment

2014

-Work experience

-Age

in

-Sales target pressure

competition

2014
2016

2014

(supervisor/employee

s/colleagues) 
INTERNATIONAL JOURNAL OF ACADEMIC RESEARCH IN BUSINESS AND SOCIAL SCIENCES Vol. 10, No. 8, 2020, E-ISSN: 2222-6990 @ 2020 HRMARS

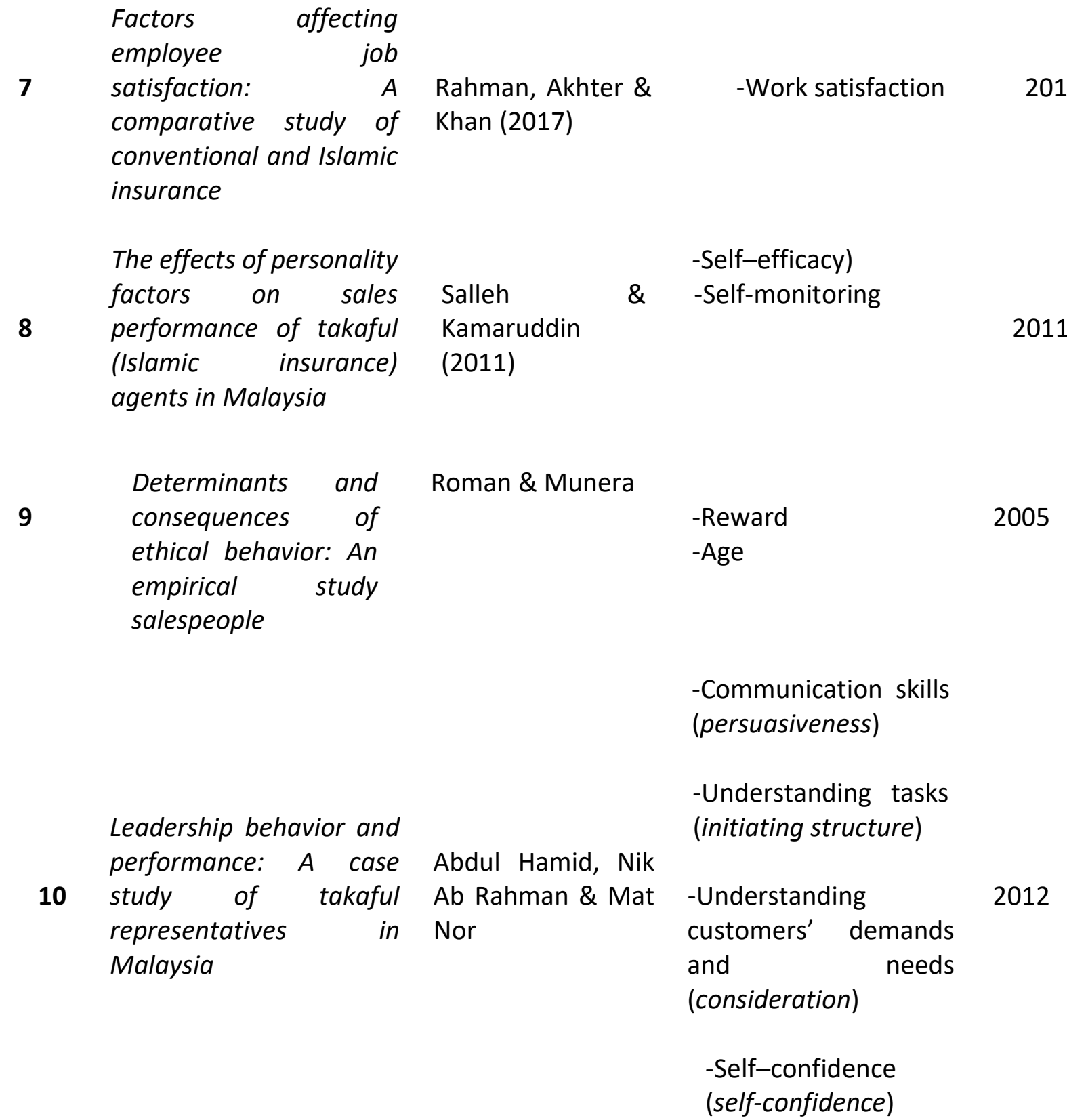

\section{Research Methodology}

This paper applies a qualitative method. The approach is chosen for its ability to present results in the form of in-depth analysis. The results stated are clearly the factors that influence ethical behaviours among takaful agents. Based on the qualitative approach, content analysis method is chosen to analyse the secondary data that are obtained from this study. Indirectly, this study will be able to contribute to takaful companies. This is because, the findings of this study can serve as a guidance for takaful companies to identify the ethical conduct among takaful agents. With this being said, the companies will be able to take appropriate steps to deal with this issue. 
INTERNATIONAL JOURNAL OF ACADEMIC RESEARCH IN BUSINESS AND SOCIAL SCIENCES Vol. 10, No. 8, 2020, E-ISSN: 2222-6990 @ 2020 HRMARS

\section{Analysis and Discussion}

Based on past research, the researchers have found at least 16 factors that influence an agent's behaviour. In this paper, the researchers have narrowed down to 6 main factors that influence a takaful agent's behaviour. The 16 factors are derived from all studies that are listed. The researchers have combined a common factor into one group and the researchers narrowed down 16 to 6 main factors based on the highest number of frequency among the studies that are listed in Table 1.

Findings have suggested that pressure on sales target is the most dominant factor that affects the behaviour of an agent. This is due to the fact that the company's target sales gives pressure to the agent as he wants to make sure that he can achieve it. Yi, Dubinky \& Lim (2012) stated that the higher pressure faced by an agent to reach a target sale, the higher probability there is for the agent to behave unethically.

Similar findings are stated by Aziz, Ghani \& Shaari (2016). They stated that an agent may act beyond his control to do unethical behaviours because he wants to reach the target sales that are fixed by a company to their agents. Consequently, their behaviours became unethical in conducting their assigned duties.

The second biggest factors are supervisor's influence, competition, role ambiguity, age and selfesteem. These five factors share similar frequency of two. For instance, supervisor's influence is seen to be the second most important factor due to the pressure given by a supervisor to his agents in grabbing more takaful users. Moreover, the influence of supervisors who keep on persisting and "pressing" agents affect their behaviours to be ethical or non-ethical. Talha, Sallehhuddin \& Masoud (2014) stated that the closest people to an agent play a prominent role in affecting their behaviours too.

Competition is also seen as a factor that affects and influence agents' behaviours as they will feel the need to compete with colleagues to reach a target sale that are fixed by a company. A close competition between agents will influence their behaviours (Yi, Dubinky \& Lim (2012).

Next, role ambiguity also acts as a major factor that influence an agent's behaviour. This occurs when agents are not suited and fitted to conduct the duties given. Role ambiguity also occurs if agent does not know how to conduct the duties given to them. The situation occurs because there is a lack of knowledge and information given on a product or service that a company offers (Hamid \& Rahman, 2011). Consequently, the agent will not be able to provide detailed information of the takaful plan to the customer. Age and self-esteem also influence the behaviour of takaful agents.

Age is one of the factors that influence an agent's behaviour Cheng, Hsieh \& Yang (2014); Román \& Munuera (2005). Agents aged 50 and above tend to behave unethically (Cheng, Hsieh \& Yang (2014). This is because these group of age have been serving in the industry for a longer time which may result them to behave in a certain way (Román \& Munuera, 2005).

Self-confidence is also one of the factors that influence an agent's behaviour. If the agent is not confident in his field of work, the probability of him not knowing to give good explanations on takaful plans will be higher. This behaviour will affect low productivity especially to the performance of takaful companies (Hamid, Rahman \& Nor, 2012). 


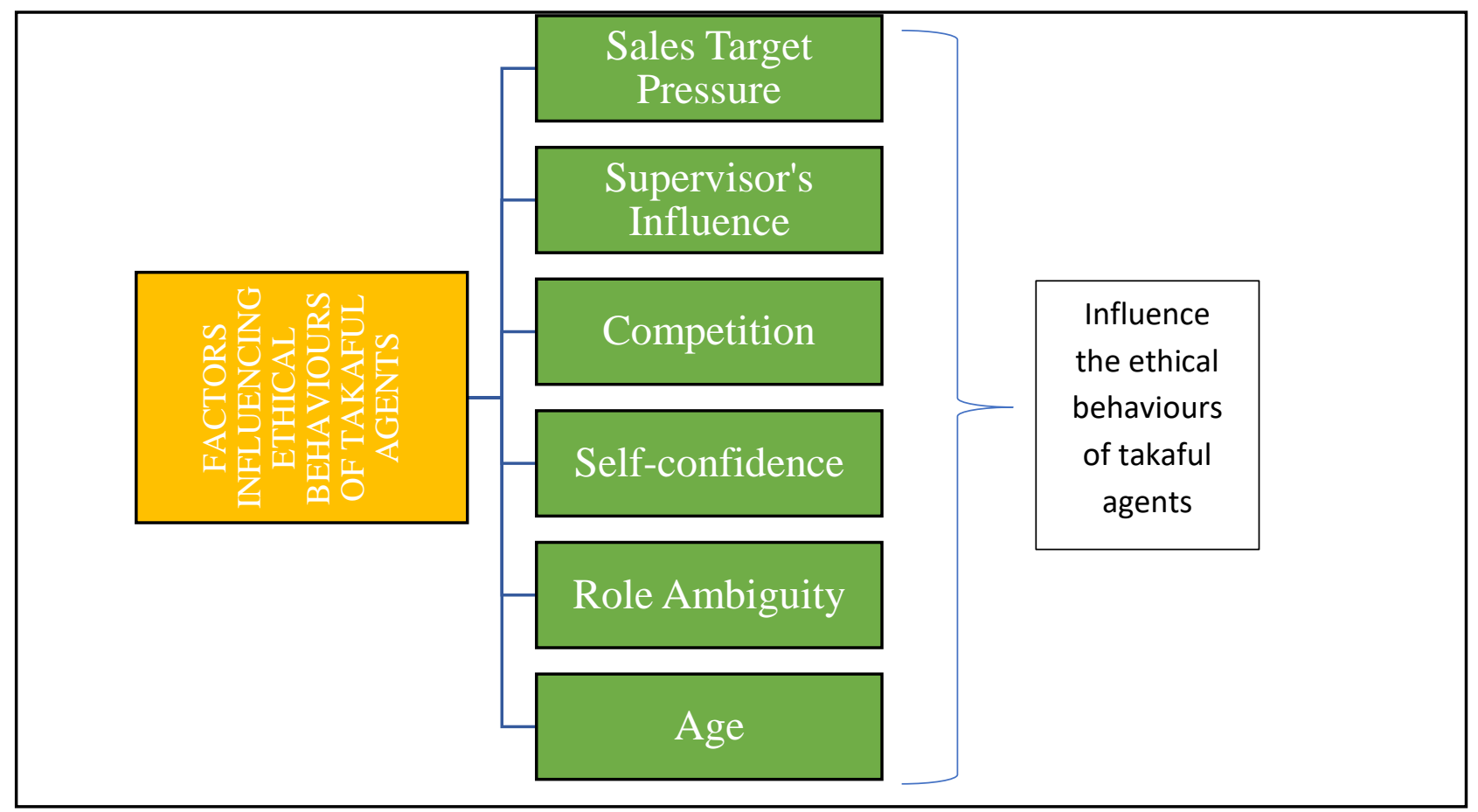

Figure 1.1 Factors Influencing Takaful Agents' Behaviours

According to Table 1 above, the researchers have narrowed down the factors that influence agents' behaviours in the form of a diagram. Despite that, the researchers have only taken into account the factors that seemed to have the highest frequency from the listed factors from past researchers. This could be analysed from Table 1.1 above. From all the factors that are listed by researchers such as in Table 1.1, the researchers are able to identify that all these factors have led to ethical issues among takaful agents.

However, after analysing the data collected from document analysis, the researchers have identified that sales target pressure is the most dominant factor that affects an agent's behaviour. Yi, Dubinky \& $\operatorname{Lim}(2012)$ stated that sales pressure is the reason for an agent to have ethical issues especially when dealing with customers. Aziz, Ghani \& Shaari (2016) hold the same view as their study reveals that unethical behaviours among agents increase due to agents wanting to increase their sales. Due to high pressure faced by agents, the probability of them acting beyond their control until they give false information is high. Apart from that, they may also hide information or persuade customers to choose products and plans that are not required.

Consequently, the issue will impact customers negatively. Agents often behave unethically to societal norms in order to achieve sales targets. As a result, agents' relationships with customers worsen and agents will lose them (Aziz, Ghani and Shaari, 2016).

Past researchers have also claimed that agents who behave unethically are also influenced by their self-confidence. To further explain, a takaful company will fix the sales target of their agents. This in return, will ensure that the agents must reach the target. In this case, agents with low self-confidence and self-esteem will feel doubtful of himself. It is not a surprise if they feel depressed or pressured to reach the takaful plan and product sales target.

Low self-confidence may influence agents to behave unethically. This includes the agents giving untruthful answers, communicate with difficulty with customers or solve customers' problems 
weakly. The situation differs with agents with high self-confidence. These agents will feel that they are able to reach certain targets and that they will work hard to do so. In other words, these group of people are the ones who are able to handle their duties well and therefore are able to convince audience to join takaful plans.

Takaful companies rely heavily on their agents to gain customers' confidence in their takaful products and services (Hamid, Rahman \& Nor, 2012). However, the factors that are listed in table 1.1 above have caused issues on unethical behaviours among customers. The remaining issues will then impact the takaful industry negatively.

Highly-principled agents who give their full commitment are likely to be influenced by their colleagues with ethical issues (Hamid, Rahman \& Nor, 2012). If the issue continues to happen, the likelihood of these good agents leaving the takaful industry will be high. This will also lead to low productivity. Apart from that, customers' trust and confidence in the agents and the takaful companies they represent will also decrease due to such unethical behaviours. Consequently, the takaful industry will suffer a huge impact.

The findings of this study show that there are three possible reasons why sales target pressure is the dominant factor in influencing takaful agents' behaviours. First and foremost, takaful companies want to boost their company's performance. This is achieved by fixing sales target to every agents to improve the company's performance. The more takaful plans and products a customer joins or claims is the indicator of a good performance (Haron, Ismail \& Razak, 2011). Therefore, an agent are forced to bear the burden and think of many creative ways to reach the target that are set by the company. Rather tshan focusing on work ethic issues, intense competition in the takaful industry forces the takaful operator to focus more on the number of plans and products that customers can join. As a result, agents have to work hard to achieve their sales targets by attracting more customers to participate in takaful.

The third possible reason why sales target pressure has the most impact on the takaful agents' behaviour is because the agent may not know the various approaches that he can apply in attracting customers to participate in a takaful plan. As they compete with their colleagues to reach their sales target, it is possible that the agent does not know how to persuade and gain customers confidence in the services provided by the agent. As agents are unable to attract customers, the pressure to achieve sales targets will be higher. When an agent feels pressured to reach a target, it is possible for the agent to act out of his control while carrying out a task. This includes behaving unethically such as fabricating personal information or takaful plan information.

\section{Summary, Implications and Suggestions}

The factors that influence a takaful agent's behaviour have led to ethical issues among them. Such ethical issues among takaful agents clearly have negatively impact the customer, company and the takaful industry on the whole. If these behaviours are not contained, it is feared that customers will lose their trust and confidence in the takaful industry for good.

Apart from that, this study also found out that sales target pressure is the most dominant factor in influencing an agent to behave unethically. Past researchers have realised that leadership in an organisation is the most crucial aspect to combat ethical issues among takaful agents. A leader in a takaful company must practice certain principles as a "driver" in the takaful agents' work. Carter (2002) have listed four principles that must be practiced in every organisations. These principles are crucial in making sure that workers feel at eased communicating with different groups of 
INTERNATIONAL JOURNAL OF ACADEMIC RESEARCH IN BUSINESS AND SOCIAL SCIENCES Vol. 10, No. 8, 2020, E-ISSN: 2222-6990 @ 2020 HRMARS

stakeholders in and outside the organisation. Second, a leader who cares about justice; Third, noncollective personal responsibility and the fourth is a leader who sees all business activities as an achievable goal. Leaders in an organization must be open to criticism, failure and suggestions. Leaders who practice ethical behaviour must always listen and accept others' views as a good example for a takaful agent. Indirectly, it will be a role model for all employees, especially takaful agents in the takaful company.

This article also recommends research in the context of leadership of managers of takaful companies. Researchers strongly believe that unethical behaviour among takaful agents is likely due to leadership pattern among top executives of takaful companies. By engaging in research on leadership, the true nature of work environment within a takaful company can be understood better.

In addition to research on leadership of takaful company managers, future research in agents' behaviour towards takaful participants can also be done extensively. The topic is interesting and crucial as researchers can identify how agents behave towards their customers. This is important because agents may possibly behave unethically towards takaful participants. It is especially true in the context of understanding customers' needs and their role in promoting takaful products and services.

\section{References}

AlNemer, H. (2015). Participants' satisfactions about Takaful products \& services: An empirical study on Saudi Arabia. International Journal of Business and Law, 7(1), 54-66.

Amin, N. M. A., \& Hamid, M. A. (2014). Shariah compliance of wakalah concept in Takaful operation: A case study of a Takaful operation in Malaysia. Tazkia Islamic Finance and Business Review, 8(2), 210-235.

Aziz, N. A A., Ghani, A. H. A., \& Shaari, H. (2016). Issues and Problems in Ethical Practices amongst Takaful Agents. International Review of Management and Marketing, 6(4S).

Bashir, M. S. (2013). Analysis of customer satisfaction with the Islamic banking sector: case of Brunei Darussalam. Asian Journal of Business and Management Sciences, 2(10), 38-50.

Carter, M. (2002). Complete guide to ethics management: an ethics toolkit for managers.

Cheng, C. Y., Hsieh, C. H., \& Yang, Y. S. (2014). Who would engage in unethical behavior? Should organizations bear the responsibility?. Quality \& Quantity, 48(4), 2341-2354.

Cheng, C., Hsieh, C., \& Yang, Y. (2013). Who would engage in unethical behavior? Should organizations bear the responsibility?. Quality \& Quantity, 48(4), 2341-2354.

Crosby, L. A., Evans, K. R., \& Cowles, D. (1990). Relationship quality in services selling: an interpersonal influence perspective. The journal of marketing, 68-81.

Djafri, F., \& Noordin, K. (2017). The impact of workplace spirituality on organizational commitment: A case study of Takaful agents in Malaysia. Humanomics, 33(3), 384- 396.

Dunfee, T. W., \& Gunther, R. (1999). Ethical issues in financial services. Business and Society Review, 104(1), 5-12.

Hamid, M. A., \& Rahman, N. A. (2011). Commitment and performance: a case of Takaful (Islamic Insurance) representatives in Malaysia. Australian Journal of Basic and Applied Sciences, 5(10), 777-785.

Hamid, M. A., Ab Rahman, N. M. N., \& Nor, N. M. (2012). Leadership behavior and performance: A case study of Takaful representatives in Malaysia. African Journal of Business Management, 6(6), 2291-2298. 
INTERNATIONAL JOURNAL OF ACADEMIC RESEARCH IN BUSINESS AND SOCIAL SCIENCES Vol. 10, No. 8, 2020, E-ISSN: 2222-6990 @ 2020 HRMARS

Haron, H., Ismail, I., \& Razak, S. H. A. (2011). Factors influencing unethical behavior of insurance agents. International Journal of business and social science, 2(1).

Haslina, C. N., Kartini, M. R., \& Norudin, M. (2016). Determinants of customer satisfaction in takaful products and services. Journal of Applied Environmental and Biological Sciences, 6(1S), 7-15.

Ishak, N. H. I. (2017). Concept paper: Customer satisfaction in Malaysian Takaful industry. International Journal of Academic Research in Business and Social Sciences, 7(3), 380- 391.

Jamil, H., \& Akhter, W. (2016). Investigating the impact of Shari'ah perception on customer switching intentions: A study of Takāful and conventional insurance. Cogent Business \& Management, $3(1), 1-11$

Lagace, R. R., Dahlstrom, R., \& Gassenheimer, J. B. (1991). The relevance of ethical salesperson behavior on relationship quality: The pharmaceutical industry. Journal of Personal Selling \& Sales Management, 11(4), 39-47.

Rahman, K. U., Akhter, W., \& Khan, S. U. (2017). Factors affecting employee job satisfaction: A comparative study of conventional and Islamic insurance. Cogent Business \& Management, $4(1)$.

Román, S., \& Munuera, J. L. (2005). Determinants and consequences of ethical behaviour: an empirical study of salespeople. European Journal of Marketing,39(5/6), 473-495

Roushdy, A. S., \& Ali, G. (2017). The impact of customers engagement repurchase intention: A mediation role of customers satisfaction - the case of Takaful insurance industry. 1- 18

Salleh, F., \& Kamaruddin, A. R. (2011). The effects of personality factors on sales performance of takaful (Islamic insurance) agents in Malaysia. International Journal of Business and Social Science, 2(5), 259-265.

Salleh, M. C. M. (2014). Islamic relationship marketing practice, customer satisfaction, and retention: A mediation analysis. Australian Journal of Basic and Applied Sciences, 8(5), 51-55

Segar, S. (2009). Buat duit sebagai ejen insurans \& takaful (1st ed.). Kuala Lumpur: PTS Professional Publishing.

Shaladdin, M., Z., Mokhtar, M., \& Zawawi, M. N. (2018). Determinants of Customer Satisfaction in Takaful (Islamic Insurance) Services in Malaysia. Jurnal Pengurusan, 54, 205-211.

Shaladdin, Z. F. M., Mokhtar, M. Z., \& Zawawi, N. H. M. (2018). Determinants of Customer Satisfaction in Takaful (Islamic Insurance) Services in Malaysia. Jurnal Pengurusan (UKM Journal of Management), 54.

Talha, M., Sallehhuddin, A., \& Masoud, M. (2014). Predictors of ethical behavior among insurance agents, 26(4), 1643-1653.

Yazid, A. S., Ariffin, J., Awang, Z., Daud, W. N. W., Zainol, F. A., Salleh, F., \& Hamid, N. A. (2017). Does education moderates the relationship between decision factors and purchase decision of family takaful protection in Malaysia. World Applied Sciences Journal, 35(9), 1849-1863.

Yazid, A. S., Ariffin, J., Awang, Z., Daud, W. N. W., Zainol, F. A., Salleh, F., ... \& Hamid,

Yi, H. T., Dubinsky, A. J., \& Lim, C. U. (2012). Determinants of telemarketer misselling in life insurance services. Journal of Services Marketing, 26(6), 403-418

Zulkifli, A. M., Abd Rahman, B. H., Yassin, N., \& Ramly, J. (2012). Amalan asas takaful. Kuala Lumpur, Malaysia: IBFIM. 